Marciniuk J., Marciniuk P. \& FyaŁKowska K. 2019. Nowe stanowisko Erechtites hieracifolia (Asteraceae) koło Różana w Puszczy Białej (Polska północno-wschodnia). - Fragmenta Floristica et Geobotanica Polonica 26(1): 176-178.

NowaK K. A. 2014. Nowe stanowisko Erechtites hieracifolia (Asteraceae) na Grojcu koło Żywca (SW Polska). - Fragmenta Floristica et Geobotanica Polonica 21(2): 395-396.

PaUL W. 2013. Rozmieszczenie roślin naczyniowych południowej części Płaskowyżu Tarnogrodzkiego i terenów przyległych. s. 526. Instytut Botaniki im. W. Szafera, Polska Akademia Nauk, Kraków.

Schube TH. 1903. Die Verbreitung der Gefässpflanzen in Schlesien preusischischen und österrechischen Antheils. s. 362. R. Nischkovsky Verl., Breslau.

ToKARSKA-GuZIK B. 2005. The establishment and spread of alien plant species (kenophytes) in the flora of Poland. s. 192. Wydawnictwo Uniwersytetu Śląskiego, Katowice.

TOKARSKA-GuZIK B. 2015. Erechtites hieracifolia, Erechtites jastrzębcowaty. - W: A. ZAJĄC \& M. ZająC (red.), Rozmieszczenie kenofitów w Karpatach polskich i na ich przedpolu, s. 86-88. Nakładem Instytutu Botaniki Uniwersytetu Jagiellońskiego, Kraków.

TOKARSKA-Guzik B., GóRski P. \& CZARNA A. 2009. Charakterystyka wybranych gatunków rozprzestrzeniających się na obszarach mokradłowych Polski. Rośliny nasienne. Rośliny jednoroczne. Erechtites jastrzębcowaty Erechtites hieracifolia (L.) Raf. ex DC. - W: Z. DAJDOK \& P. PAWLACZYK (red.), Inwazyjne gatunki obce ekosystemów mokradłowych Polski, s. 36-37. Wydawnictwo Klubu Przyrodników, Świebodzin.

Tokarska-Guzik B., Dajdok Z., Zając M., Zając A., Urbisz Al., Danielewicz W. \& HoŁdyński Cz. 2012. Rośliny obcego pochodzenia w Polsce ze szczególnym uwzględnieniem gatunków inwazyjnych. s. 197. Generalna Dyrekcja Ochrony Środowiska, Warszawa.

Wolanin M. 2014. Rośliny naczyniowe Pogórza Przemyskiego i zachodniej części Płaskowyżu Chyrowskiego. - Prace Botaniczne 47: 1-383.

ZAJĄC A. \& ZAJĄC M. 2001. Atlas rozmieszczenia roślin naczyniowych w Polsce. s. xii + 714. Nakładem Pracowni Chorologii Komputerowej Instytutu Botaniki Uniwersytetu Jagiellońskiego, Kraków.

WaCŁAw BARTOSZEK, Zakład Mykologii, Instytut Botaniki im. Władystawa Szafera Polskiej Akademii Nauk, ul. Lubicz.46, 31-512 Kraków, Polska; e-mail: w.bartoszek@botany.pl

Wptynęto: 28.10.2019 r.; przyjęto do druku: 05.12.2019 r.

DOI: https://doi.org/10.35535/ffgp-2019-0042

\title{
Nowe stanowisko Potamogeton nodosus (Potamogetonaceae) w Karpatach polskich
}

Potamogeton nodosus Poir. (rdestnica nawodna) jest jednym z ponad 20 gatunków rdestnic występujących w Polsce (RUTKOwski 2011). Jest to hydrofit o trwałym kłączu, z pączkami zimowymi w części szczytowej. Łodyga może osiągać 2,5 m długości. W sprzyjających warunkach wytwarza dwa rodzaje liści: pływające po powierzchni wody i całkowicie zanurzone. Liście są charakterystycznie siateczkowato unerwione, u nasady klinowate, co pozwala odróżnić gatunek od innych, podobnych gatunków rdestnic (ZALEWSKA-GAŁOSZ \& OKLEJEWICZ 2008; SzOSZKIEWICZ i in. 2010). 
Siedliskiem gatunku są zazwyczaj wolno płynące rzeki, dość rzadko występuje w wodach stojących, jeziorach i starorzeczach (ZALEWSKA-GAEOsZ \& OKLEJEwICZ 2008). Spotykana jest do głębokości $3 \mathrm{~m}$, dobrze znosi wahania poziomu wody (SzoszKIEwicz i in. 2010). Potamogeton nodosus jest gatunkiem charakterystycznym dla zespołu Ranunculetum fluitantis (MATUSZKIEwICZ 2015). Na siedliskach wtórnych, synantropijnych może występować z przypadkowymi hydrofitami (ZALEWSKA-GAtOSZ \& OKLEJEWICZ 2008).

Potamogeton nodosus ma zasięg holarktyczny dysjunktywny, występuje w środkowej i wschodniej Europie i Ameryce Północnej (ZALEwSKA-GAŁosZ \& OKLEJEwICZ 2008). $\mathrm{Na}$ „czerwonej liście” zagrożonych gatunków IUCN ma status gatunku najmniejszej troski LC (LANSDOwn 2017). W Polsce jest dość rzadki, występuje głównie w większych rzekach, np. w Warcie, Wieprzu, Sanie, Wiśle i Narwi, najczęściej w południowej części kraju (ZALEWSKA-GAŁosz 2008). W Karpatach polskich znane są jedynie trzy stanowiska tego gatunku. Znajdują się one w dolinie rzeki Skawy w miejscowości Dąbrówka w Beskidzie Makowskim, w Hłomczy na Pogórzu Dynowskim oraz w Rzeszowie, na krańcu Pogórza Strzyżowskiego, gdzie był stwierdzony w zbiornikach pochodzenia antropogenicznego (Ryc. 1). Zarówno według Polskiej czerwonej listy paprotników i roślin kwiatowych, jak i według Czerwonej księgi Karpat polskich, P. nodosus ma status gatunku narażonego na wyginięcie VU (ZALEWSKA-GatosZ \& OKLEJEwICZ 2008; KAŹMIERCZAKOWA $\mathrm{i}$ in. 2016).

W 2017 r. na przełomie lipca i sierpnia odkryto nowe stanowisko gatunku znajdujące się na obszarze Pogórza Rożnowskiego, w miejscowości Tropie, w kwadracie ATPOL EF 9449 $\left(20,65207^{\circ} \mathrm{E}, 49,79569^{\circ} \mathrm{N}\right)$. Stanowisko znajduje się w obrębie Zbiornika Czchowskiego, $200 \mathrm{~m}$ na wschód od wysepki zlokalizowanej w jego południowej części.

Zbiornik Czchowski jest sztucznym zbiornikiem zaporowym, utworzonym na rzece Dunajec w latach 40. XX w. Powierzchnia zbiornika wynosi 346 ha, a głębokość maksymalna 9,5 m. Linia brzegowa ma długość $23 \mathrm{~km}$. Całkowita pojemność zbiornika wynosi

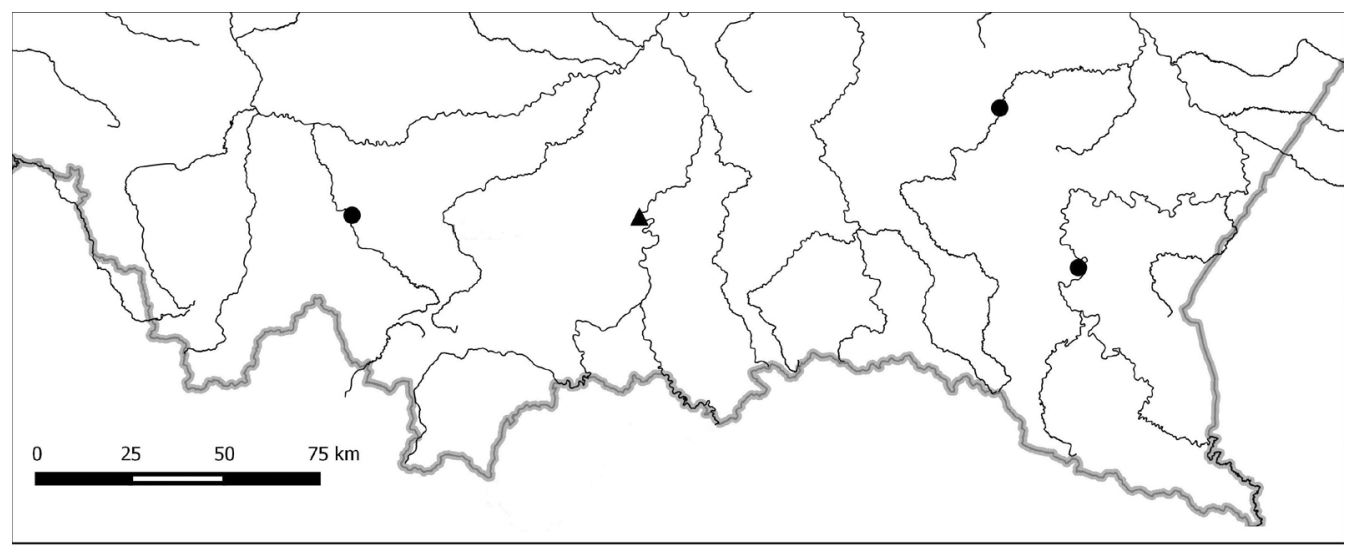

Ryc. 1. Rozmieszczenie Potamogeton nodosus w Karpatach polskich: $\bullet$ - stanowiska gatunku wg Czerwonej ksiegi Karpat polskich (ZaLEWSKA-GatosZ \& OKLeJEwICZ 2008), $\mathbf{\Lambda}$ - nowe stanowisko

Fig. 1. Distribution of Potamogeton nodosus in the Polish Carpathians: $\bullet$ - localities according to the red list of the Polish Carpathians (ZaLewSKa-GaŁosZ \& OKLEJEwicz 2008), $\mathbf{\Delta}$ - new locality 


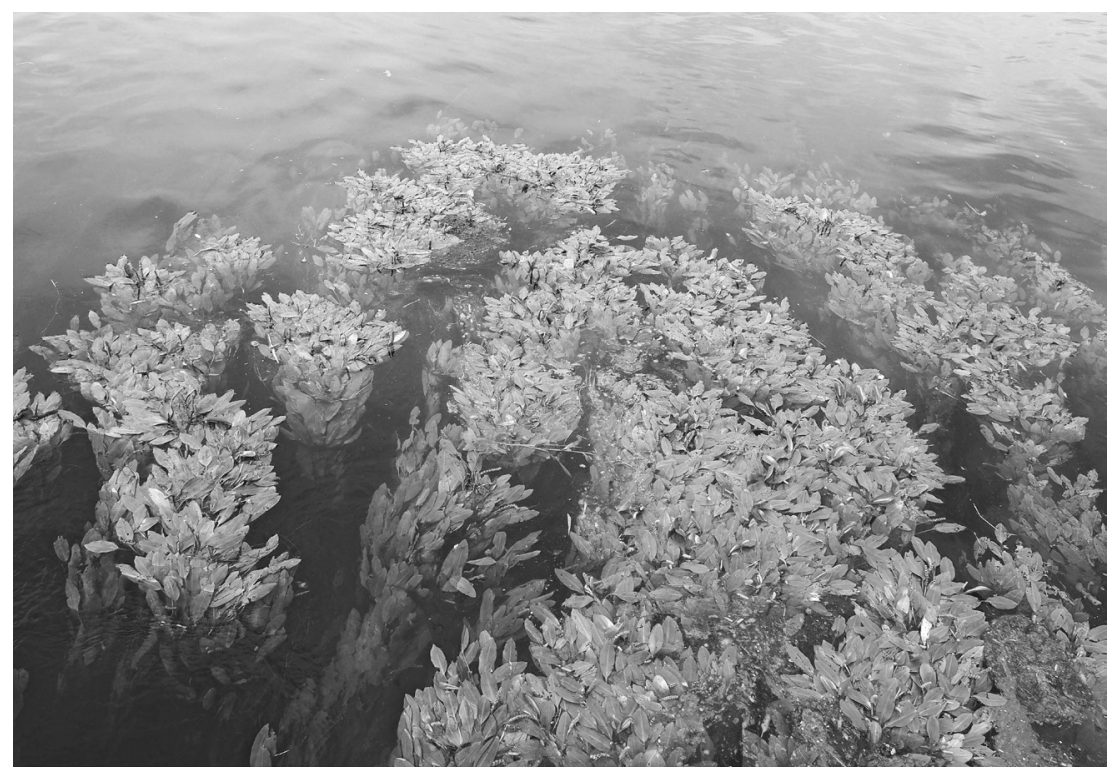

Ryc. 2. Potamogeton nodosus stwierdzony w Zbiorniku Czchowskim w 2017 r. (fot. S. Klich)

Fig. 2. Potamogeton nodosus found in Czchowski Reservoir in 2017 (photo by S. Klich)

$12 \mathrm{mln} \mathrm{m}^{3}$. Według dostępnych badań Wojewódzkiego Inspektoratu Ochrony Środowiska, woda w Zbiorniku Czchowskim nie wykazuje zróżnicowania w warstwie powierzchniowej i naddennej i odpowiada II klasie czystości. Zawartość tlenu rozpuszczonego wynosi 7,4-10,8 $\mathrm{mg} \mathrm{O}_{2} / 1$, a przeźroczystość wody 0,7-1,5 m. Zawartość zawiesin odpowiada I klasie czystości (4-13 mg/l). Stężenie substancji biogennych odpowiada II klasie czystości we wskaźniku azot azotynowy - wartości są w granicach 0,014-0,026 mg N/l. Koncentracja chlorofilu ,a” w okresie wiosennym i jesiennym kształtuje się na poziomie I klasy czystości w wartościach $1,6-4,5 \mathrm{mg} / \mathrm{l}$, a w okresie letnim osiąga poziom II klasy czystości - wartości w granicach 10,2-13,4 $\mu \mathrm{g} / \mathrm{l}$ (krakow.pios.gov.pl).

W miejscu występowania Potamogeton nodosus tworzył gęste monogatunkowe agregacje (Ryc. 2). Powierzchnia lustra wody zajęta przez pływające liście wynosiła około $30 \mathrm{~m}^{2}$. Rośliny w czasie identyfikacji były w stanie owocowania, w dobrej kondycji, bez oznak chorobowych. Zbiornik w tym miejscu jest przegłębiony, głębokość wody wynosi około 2-3 m. W innych częściach zbiornika głębokość wody często nie przekracza 1-1,5 m. Nie stwierdzono istotnych zagrożeń dla trwałości populacji.

Podziękowania. Autorzy składają podziękowania Pani dr hab. Joannie Zalewskiej-Gałosz za potwierdzenie oznaczenia gatunku.

Summary. New locality of Potamogeton nodosus (Potamogetonaceae) in the Polish Carpathians. Potamogeton nodosus is one of over 20 species of pondweed in Poland, occurring mainly in the south part of the country. Previously only three localities of this species were known in the Polish Carpathians. A new locality of it was found in Czchowski Reservoir in $2017\left(20.65207^{\circ} \mathrm{E}, 49.79569^{\circ} \mathrm{N}\right.$, ATPOL square EF 9449, Pogórze Rożnowskie foothills; Figs 1, 2). The population occupied $\sim 30 \mathrm{~m}^{2}$ of the water surface. No threats to the habitat of the population were noted. 


\section{LITERATURA}

Kaźmierczakowa R., Bloch-OrŁowska J., Celka Z., Cwener A., Dajdok Z., Michalska-Hejduk D., Pawlikowski P., SzcZęśniaK E. \& ZiarneK K. 2016. Polska czerwona lista paprotników i roślin kwiatowych. s. 44. Instytut Ochrony Przyrody, Polska Akademia Nauk, Kraków.

LansDown R. V. 2017. Potamogeton nodosus. The IUCN Red List of threatened species 2017: e.T164227A67791533. http://dx.doi.org/10.2305/IUCN.UK.2017-1.RLTS.T164227A67791533.en. (dostęp: 27.03.2019).

MatuszKiewicz W. 2015. Przewodnik do oznaczania zbiorowisk roślinnych Polski. PWN, Warszawa.

RUTKOwSKI L. 2011. Klucz do oznaczania roślin naczyniowych Polski niżowej. s. 816. PWN, Warszawa.

SzoszKIEWICZ K., JUsiK S. \& ZGOŁA T. 2010. Klucz do oznaczania makrofitów dla potrzeb oceny stanu ekologicznego wód powierzchniowych. s. 308. Biblioteka Monitoringu Środowiska, Inspekcja Ochrony Środowiska, Warszawa.

Zalewska-GaŁosz J. 2008. Rodzaj Potamogeton L. w Polsce: taksonomia i rozmieszczenie. s. 218. Instytut Botaniki Uniwersytetu Jagiellońskiego, Kraków.

Zalewska-Gatosz J. \& OKLeJewicz K. 2008. Rdestnica nawodna Potamogeton nodosus Poir. - W: Z. Mirek \& H. PięKoś-MiRkowa (red.), Czerwona księga Karpat polskich. Rośliny naczyniowe, s. 414-415. Instytut Botaniki im. W. Szafera PAN, Instytut Ochrony Przyrody PAN, Kraków.

Sabina Klich, Alina Stachurska-Swakoń, Instytut Botaniki Uniwersytetu Jagiellońskiego, ul.Gronostajowa 3,30-387 Kraków,Polska; e-mail: sabina.klich@doctoral.uj.edu.pl

Wptynęto: 03.04.2019 r.; przyjęto do druku: 24.09.2019 r.

DOI: https://doi.org/10.35535/ffgp-2019-0043

\section{Górski gatunek Festuca drymeia (Poaceae) w rezerwacie „Wzgórze Joanny” (Nadleśnictwo Milicz) na Dolnym Śląsku}

Festuca drymeia Mert. \& W. D. J. Koch (kostrzewa górska) należy do europejsko-umiarkowanego podelementu o alpejsko-środkowoeuropejskim typie zasięgowym (ZAJĄC \& ZAJĄC 2007). W Polsce występuje dość często we wschodniej części Karpat Zachodnich oraz na obszarze Beskidów Wschodnich należących do Karpat Wschodnich - w piętrze pogórza i piętrze regla dolnego (ZAJĄC \& ZająC 2001; MiReK \& PięKOŚ-Mirkowa 2007). Z terenów niżowych Polski dotychczas nie była podawana (ZAJĄC \& ZAJĄC 2001).

Nasze badania dostarczają nowe, dotychczas nienotowane stanowisko niżowe Festuca drymeia z rezerwatu „Wzgórze Joanny” (Nadleśnictwo Milicz) koło Milicza. Rezerwat o powierzchni ponad 24 ha powstał w 1962 r. Na szczycie znajduje się dziewiętnastowieczny zamek myśliwski z wieżą widokową, do którego prowadzi ścieżka dydaktyczna objaśniająca walory historyczne i archeologiczne wzgórza, jak również szczegóły przyrodnicze występujących w rezerwacie buczyn. Na terenie chronionym znajduje się również znalezisko prehistoryczne. Cały rezerwat porośnięty jest przez kwaśne buczyny niżowe Luzulo pilosae-Fagetum. Fagus sylvatica występuje tutaj wyspowo na wschodniej granicy jego zasięgu. 